AT a recent meeting of the Franklin Institute it was shown by $\mathrm{Mr}$. Grimshaw that the microscope may be of gool service in estimating the value of structural materials. It may determine whether or not the material is good enough to warrant trial with the testing machine. The author produced photographs of a chip of timber from a highway bridge that was wrecked two years ago, after a few days of service, through the strain caused by an empty truck; and the foor character of the wood was at once apparent. Such micro-photographs of timber, in fact, show that in the strong specimens, the concentric rings are close in texture and of slight width, and the radial plates frequent, wide, long, and thick, while the reverse is found in the poor material. As a parallel in metal-work, Mr. Grimshaw exhibited two portions of pure Lake copper, one an ordinary ingot, of coarse and crystalline grain, dark red colour, and full of blowholes; the otber, cast with proper precautions against oxidation, the grain close and fine, the colour salmon, and no blowholes. Tests of tensile strength of sheet and wire from these materials strikingly confirmed the indications of the microscope.

THe Fournal of the Franklin Institute for September contains a fine plate (produced by the phototype process invented by $\mathrm{Mr}$. Jacobi, of Ncuendorf-Coblentz), representing the great bell of Moscow, from a photograph recently taken by Mr. Nystrom, who gives some interesting information about the largest ringing bells in the world.

AN attempt has been made by Signor Serpieri to connect, in an indirect way, two very dissimilar phenomena, viz., the attraction of the sun and moon, and the periodical revival of vulcanism in its more common manifestations. He finds support for his view (Reale Ist. Lombard., August 3 ) in a recent observation by M. Daubrée in the deep gallery (for the Channel tunnel) made in the Rouen chalk, where it was noticed that the pits showed oscillations of level quite concordant with the varying tide above, the water abundant at high tide, and scanty at low tide; which is easily understood (says M. Daubrée), since all aquiferous strata there pass under the sea. Accepting this variation in the water of terrestrial depths with the sea-level, and knowing, on the other band, that sea water has a principal part in the activity of volcanoes (as proved by the nature of their products and the immense quantity of aqueous vapour, which cause and maintain eruptions), it is natural, Signor Serpieri says, to conclude that the volcanic activity must present phases agreeing with those of the tide, and thus there appears a certain connection with the age and the position of the moon. Observations of a large number of earthquakes should also present the relation in question, as these are known to be mostly of volcanic origin, and to preferably affect coast regions; and $M$. Perry observed they were more frequent at syzygies and perigee of the moon. Prof. Bombicci has also observed in some parts of Italy a greater frequency of earthquakes at times of heavy and prolonged rains, which he regards as the exciting cause in such cases; and precisely because not all seismic centres are fed with sea-water, it is vain to expect that the Iuni-solar influence on earthquakes may be always made out. Thus the anomalies recorded by Schmidt and others may be explained.

THE additions to the Zoological Society's Gardens during the past week include a Rude Fox (Canis rudis) from Demerara, presented by Mr. W. F. Bridges; three Common Hedgebogs (Erinaceus curopaus), British, presented by Mr. W. Bayes ; two Chimachima Milvagos (Milvago chimachima) from Demerara, presented by Mr. G. H. Hawtayne, C.M.Z.S. ; a Common Barn Owl (Strix flammea), Britisb, presented by Mr. G. Paul; a Purple-headed Glossy Starling (Lamprocolius auratus) from West Africa, presented by Mr. J. Biehl; a Radiated Tortoise (Testudo radiata) from Madagascar, presented by Capt. R. Elwood; a Blue-crowned Hanging Parrakeet (Loriculus galgulus) from
Ceylon, deposited; a Polecat (Mustela putorius), British, a Bengal Pitta (Pitta bengalensis) from India, purchased; four Banded Grass Finches (Poëphila cincta), bred in the Garders.

\section{UNWRITTEN HISTORY, AND HOW TO READ IT 1}

II.

$\mathrm{BUT}$ the flint arrow-heads and scrapers, and the use of stone for battle-axes, car,y us back to a still earlier chapter of unwritten history, when, for want of knowledge of bronze or any other serviceable metal, our predecessors, like many a savage people of recent or comparatively recent times, had to make use of such materials as readily came to their hands-like stone, wood, and bone-for all ordinary appliances. With relics of this period, which, so far as those made in stone are concerned, are alm cst imperishable, the soil of this country in many districts abounds. We also find the tools and weapons of this Stone Age in many of the grave-mounds or barrows and beneath the floors of some of our caverns. It is by means of these relics that the history of this period is to be read, but here also much is to be learnt from the early lake-habitations of southern Europe and from the habits of savages in other lands who are unacquainted with the use of metal. It is indeed somewhat remakable that those in so low a stage of civilisation should have been able to furnish themselves with so many and such Ferfect applicances made of stone. Not only do we find hatchets and adzes of flint and other hard stones, with their edges carefully ground. but chisels, and even gouges or hollowed chisels (I hough these are rare in Britain), drills or awls, hammers knives, saws, and scraping tools of various kinds. One of the most common of these is made from a flat splinter, or flake of flint, trimmed at the end to a semicircular scraping edge. We still find such tools in use for the purpose of preparing skins; and we have corroborative evidence of their having been in use in old times for some such purpose, in the fact that the semicircular edge is often worn away and rounded in precisely the way that would result from its being used to scrape a soft but gritty substance, such as leather exposed to du:t and dirt. Though skins probably formed the principal clothing, the presence of spindle-whorls-the small fly-wheels by which spinning by hand is carried on-in some sett'ements of the Stone Period, proves that the art of spinning was not unknown, and indeed charred fragments of woven linen cloth have been found in some of the lake dwellings of this age. The stone-using people of that time cultivated wheat, barley, and millet for their bread, which they ground into ccarse flour by means of rubbing-stones; they flavoured their cakes with carraway and poppy seeds, and laid up stores of nuts and walnuts, beech-mast and acorns, apples and pears for winter use, and ate all the common wild fruits in their seasons.

All this we learn from the charred remains left at the bottom of the lakes where the pile-dwellings were burnt down. The bones thrown away show that not only did they hunt wild animals of the country, but that they had oxen, sheep, and goats, and probably also pigs, as domesticated animals, and the dog was already their faithful companion. Their weapons for the chase were arrows and spears tipped with flint-the former of which, being cheaper than metal and also liable to be lost, remained in use even when bronze was known. They also possibly made use of the sling. Their axes, like modern tomahawks, seem to have been used both for peaceful and warlike purposes, but in this country at least it is doubtful whether any of the stone battle-axes with a hole for the haft belong to an earlier date than the simplest of the bronze daggers. From an examination of the skulls and bones found in the graves of the Stone and Bronze Periods we are able to form an idea of the size of the men of those days, and of the differences between them. From the oljects bur:ed with them we can even form some idea of their religious beliefs and hope of a future state. I mu:t not, however, dwell on the details of these chapters in the unwritten history of man in Britain. I may, however, observe that though we may fix $"$ ithin some cen'uries the date when bronze began to be employed for cutting-tools, and stone in consequence began to fall in disuse, we aré as yet at a loss to say at how early an epoch the use of the stone hatchets with

I A lecture to the wring classes, delivered at the meeting of the British Association $\mathrm{f} \rightarrow \mathrm{r}$ the advancement of science, held at Scuthampton, August ז882, by J' hn Evans, D.C.L., LL.D., F.R.S., \& c. Revised by the Auth 3 r. Continued from p. $5 \times 6$ 
their edges ground or polished first began. The period during which they were exclusively employed has been called the Neolithic or New Stone Period. It has also been called the Surface Stone Period, as the relics belonging to it are usually found upon or near the surface of the ground, and not at a considerable depth below it, like those belonging to an earlier chapter in our history, which actually form constituent parts of extensive geological deposits. There is this also to be observed, that the circumstances under which the stone implements of this periods are found, prove that no very great alteration in the general features of the country has taken place since the time when they were in use There was the same disposition of hill and valley; rivers ran along much the same course as now, and at much the same level; the same animals frequented the country with but few exceptions, and though there may bave been incursions of foreign races of men, we find the Stone Age shading off into the Bronze Age, and the latter into the Iron Age, not many centuries before the Roman occupation Although it is impossible to say for what length of time this Neolithic or Surface Stone Period may have endured in Britain, there is little on the face of the facts which of necessity implies a longer existence for the human race than the six thousand years that used commonly to be assigned to it. In other parts of the world, as for instance in Egypt, there have been circumstances brought to light which prove that the ordinary chronology is insufficient for the history of those countries; and, in addition, there are facts known with regard to the development of language which have led many students to the conclusion that the antiquity of man is much greater than was commonly supposed. And yet five-and-twenty years ago, or less, there was no one who could point to traces of human occupation in Britain of an earlier date than the polished stone instruments. I might, perhaps, make an exception in favour of $\mathrm{Mr}$. John Frere, who, at the beginning of this century, inferred frrom the circumstances under which some stone weapons were found, that they belonged "to a very remote period indeed, even beyond that of the present world."

If it had been my lot to address you in $185^{8}$ instead of in I882, I should myself have assured you that the earliest chapter in our unwritten history was that which related to the polished stone hatchets and the other forms of stone weapons and instruments which are found associated with them. At the same time I should not have agreed with Dr. Johnson, that " all that is really known of the ancient state of Britain is contained in a few pages. We can know no more than the old writers have told us." But within the last twenty years what a lengthened vista of the antiquity of our race has been opened out, and what a marvellous chapter of unwritten history have we not to some extent been able to read!

It is to that chapter that $\mathrm{I}$ must now turn, and, in examining it, it will perhaps be best first to state some of the facts which of late years have come to our knowledge, and then to show what inferences have been drawn from them.

Geologists have long been aware that along the valleys of our principal rivers, generally at some height above their present level, and often at some distance from the streams, there are beds of gravel, sand, and brick-earth, frequently containing the remains of land and fresh water shells, and the bones of various animals. That these drift-deposits were not due to the action of the sea is shown by the absence of sea-shells, while the general resemblance of the land and fresh-water shells in them to those in the existing stream and valley prove them to have been deposited by fresh water. The presence in the beds of the bones of land animals is also corroborative of this view while the fact that several of these beast, such as the great woolly elephant or mammoth, the rhinoceros, hippopotamus, and reindeer, are of species now extinct, or no longer known in Britain, is suggestive of remote antiquity. In some cases shells and bones have not been found, but the position and character of the beds are such as to prove that they belong to the same class, and are of the same age, as those in wbich such remains occur. Here at Southampton we are on the tongue of land which separates the valleys of the Trst ard the Itchen, but the drift-beds in these valleys have not been as yet very carefully examined above Southampton, though at Swathling an elephant's tooth has been found in the gravel. The next valley westward, that of the Avon, which runs into the sea at Christchurch, has been more productive. Along that valley numerous beds of drifted deposits have been examined, and at Salisbury, besides land and fresh-water shells, the bones of elephant, rhinoceros, hyæna, lion, and reindeer have been found in them, as well as those of $\mathrm{s}$.me other animals, among which the pouched marmot and the Greenland lemming may be mentioned. These are especially indicative of a cold climate, as are also some egg-shells of the wild goose, which now only breeds in northern latitudes. Some of the drift-beds are at a considerable height, as much as 90 or 100 feet above the existing river, but others are at a much lower level. They consist of materials assorted in much the same manner as would be effected by any existing stream-of gravels more or less coarse where probably the current bas been strong, of sand where its force has been less, and of brick-earth or mud such as might be deposited by the waters of a flooded river, or brought down the hill-sides by rain. It is impossible to imagine any floods of such magnitude as to fill the valley to the height of IOO feet; but if such floods ever did occur they would certainly not have deposited coarse gravel at the top of the banks of the stream, but at the bottom of its bed. Nor could we expect to find deposits of loam left half-way down the slopes of a river liable to such floods. From these and other grounds we are driven to the conclusion that the beds of drift, which are now roo feet or more above the existing river, at one time formed a portion of its bed when it ran at a much higher level than at present, and that, by the action of the stream running along it, the valley has since that time been scooped out to its present depth. The climate at the time of the deposit of the high-level gravels appears to have been cold, so that both frost and a much larger rainfall may have assisted the stream in producing greater effects upon the valley than it now does. The river also, when left to itself, and neither watched nor embanked, would be far more liable to floods which might wear away the valley. Under any circumstances the scooping-out to such a depth must have required an enormous amount of time, and it is hard to picture to one's self what the country must have been like in those days when the beds of the rivers at some little distance from the sea were, say, Ioo feet abrive their present level. Here at Southampton we have beds of the e old gravels capping the hill at the Common at something like I 50 feet above the sea-level, and yet the top of this hill must at the tin e of their dep-osit have been the bottom of a valley with hills on either side. As old as the hills is a proverbial phrase, but, compared with the age of the hills at the side of the valley which has disappeared, this bill is a thing of yesterday -

$$
\begin{aligned}
& \text { "The hills are shadows, and they flow } \\
& \text { From form to form and nothing stands. } \\
& \text { They melt like mists the solid lands, } \\
& \text { Like clouds they shape themselves and go." }
\end{aligned}
$$

Some of you will begin to think that I have not kept my promise, but have strayed into the geslogical past. When, however, I tell you that implements made of flint, as undoubtedly the work of intelligent beings as any Sheffield whittle of the present lay, form constituent parts of the gravel of which $I$ have been speaking, and are also found scattered through the sands and loam, you will perceive that I am still within the limits of the unwritten history of the human race.

Before proceeding further with regard to the circumstances under which the implements are found, it will be well to say a few woris as to their character and probable uses. Some of them are large flat splinters or "flakes" of flint, detached from a block by a single blow, in the same manner as flakes of flint are still prociuced in the manufacture of gun-flints. The edges if such flakes are very sharp, so they may have been ued as knives. When found in gravel they have usually been much knocked about, but when fourd in sand or clay the edges often show traces of wear, as if they had been u-ed for scraping bones or some such hard substance as well as for cutting. The more highly wrought implements are sometimes oval, with a cutting edge all round, and sometimes provided with a ?harp or rounded point. The oval specimen shown in the diagram was found in $a$ pit at the north end of Southampton Common, and the other two near Barton, between Lymington and Christchurch. These implements are chipped out with considerable skill, and may have been used either as weapons for the chase or for the war, or as tools for cutting, grubbing, or piercing. The extreme point of one of the specimens figured has been worn away at each side, as if it had been used for roring a hole. Some of the instruments may have been mounted with hafts as-axes or spears, but of this there is at present no conclusive evidence. The larger number of them appear to te well-adapted for holding in the hand, and it is to be observed that their broad end is usually blunt, and the narrow end sharpened for use; whereas 
in the instruments of the Surface Stone Period it is nearly always the broad end that is sharpened, and this has often been effected by grinding or polishing the edges, while in the implements of the period we are now considering the edges are never ground. The name by which this period is generally known is the Palæolithic or Ancient Stone Period, though it is sometimes also termed the River-drift Period, as the implements belonging to it are usually found in river-drift. Of the other appliances in use among those who made the large palæolithic implements we can best judge by the remains which have been found beneath the floors of some of the caverns both of England and France, which, however, for the most part probably belong to a somewhat more recent date. In the days when those caverns were occupied as dwellings the reindeer still formed a principal article of food in the South of France. Those who hunted it were sufficiently good artists to carve figures of it in bone, or to engrave them on slabs of slate. Some representations of the elephant have also been found. They carved harpoons in reindeer horn, prepared skins with stone scrapers, and sewed them together by means of bone needles, probably using reindeer tendons as thread. The men, however, who were in this state of civilisation lived at a time when the valleys had been excavated to nearly their present depth, Yet even between them and the people of the Neolithic or Surface Stone Period there appears to be a great gulf-a chapter of unwritten history, which at present we have no means of reading.

Let us now return to the river-drift, and see what more it can teach us. I have told you how on the high ground where now is Southampton Common there are beds of gravel containing water-worn flint implements, and that these beds must in all probability have been deposited in the bottom of a river valley. Farther south we find gravels of a similar character, but at lower levels, forming cliffs of no great height along the sea-shore from Hambley to Alverstoke. These cliffs are now being eaten away by the action of the sea, and among the pebbles spread by the waves upon the skore numerous well-wrought implements have been found, while farther east, at Selsey, there are extensive drift-beds containing remains of the mammoth. Nor are traces of the river, which ceposited these beds, wanting on the other side of Spithead, for in the shingle at Bembridge implements of the same kind have been discovered, and $\mathrm{Mr}$. Codrington found a good specimen, some 80 feet above the present sea-level, in gravel on the Foreland at the east end of the Isle of Wight.

It will probably be some little strain upon your powers of imagination for you mentally to fill up the great channel of the sea which we know as Southampton Water, and which now forms the basis of the prosperity of this town, and to picture to yourselves a river flowing in the same direction, spreading out gravels along its changing course at a height considerably above the present sea-level, and yet having its shores frequented by that early race of men who fashioned the implements which we find in the gravels. But I shall have to make a still further demand upon your powers of belief.

I have already spoken to you about the drift-deposits along the valley of the Avon, but I mu t now take you a little farther west, and call your attention to diccoveries which have been rade at Bournemouth. There, as many of you no doubt remember, the cliffs are formed of beds of sand and clay belonging to a period a little older, geologically speaking, than the Bracklesham beds whch form the subsoil of Southampton. These cliffs are, however, capped with gravel ; and in this, also, at a height of more than I 20 feet above the sea-level, implements have been found. Farther east, near Boscombe, the height of the gravel is still about $\mathbf{1} 20$ feet; at Hengistbury Head it is 90 feet; and at Barton and Hordle, where numerous implement have been fousd, it is 60 or 70 feet. There can, indeed, be but little doubt that these gravels which now cap the cliffs must originally have been deposited in the bed of a river, and that that river flowed in an easterly direction. But how, it will be asked, can any river have possibly taken such a course? I will ask you, in return, Of what are the Needles at Alum Bay the relics? Are they not the shattered and sea worn remains of an extension of the great chalk ridge of High Down westward from Freshwater? Can you not imagine them still forming part of the down, with other Needles, which have now disappeared, towering still farther to the west? Can you not picture to yourselves the foreland of Ballard Down, on the Dorset coast, and its accompanying pinnacles standing out still farther to the east, and thus in your mind's eye gradually bridge over the gap of fifteen miles, which now exists between the chalk downs of
Dorset and those of the Isle of Wight? There must almost of necessity have been a period when these two ranges of downs formed one continuous ridge, and wh $\mathrm{n}$, in fact, the Isle of Wight was not separated from England by any arm of the $s \in a$. At that time the rivers which now discharge their waters at Poole, at Christchurch, at Lymington, and at Exbury, must all have been contributed to form a river the course of which must have been from west to east, in a direction nearly parallel to the chalk downs. Of the bed of this river we have traces in the gravels $w$ hich now cap the cliffs of our southern coast. The history of the disappearance of this ancient river appears susceptible of being traced. We know not how far the land may have extended to the south of the chalk downs at the time when it first began to flow; but in the course of long ages the neverceasing wear of the sea,slow but:ure in its action, must have effected a breach through the line of chalk downs, and have then more rapidly cut away some of the softer beds to the north, so as to afford a new means of access by which the waters of the river would find a way to the sea. As itime went on this breach would become wider and wider, until, as we see at present the whole of the southern slope of the old river valley disappeared for a distance of fifteen miles between Ballard Down and the Needles; while that part of the bed of the old river which still had land to the sc uth was widened out until it became the Solent Sea and Spithead, which now separates the Isle of Wight from the mainland.

I might have given you evidence from which it has been concluded that, at the period when the river gravels containing flint implements were deposited, England was still united to the Continent, and the Straits of Dover did not exist. I might have pointed out the existence of similar implements discovered under nearly similar circumstancss in remote quarters of the world. But time will not suffice, and you must be content with my attempt to read this chapter of local history. I must, however, warn you against supposing that, old as may be these relics they repre-ent the fir-t advent of man upon the earth. On the contrary, their similarity in so many reyions points to some early home of the human family from which the makers of these flint tools in different countries originally migrated. Of this home, however, as yet no traces have been found. As to the number of years embraced in this chapter of the river-drift it is hard even to speculate. It can only be judged by the changes which have since taken place. We have seen how in the Roman times this part of Britain was, so far as the distribution of land and water is concerned, much the same as at present, and that there can bave been but little difference in the days when bronze was in use for cutting-tools or in that lengenthened period when stone did duty for steel. But when we come to this earlier chapter in our history, all is charged. We find on the top of our hills and the capping of our cliffs gravels which must have been deposited at the bottom of rivers, but which testify to the exi-tence of man at the time of their deposit. We find a total change in the animal world of the region; we find that deep valleys have been excavated and river-courses widened out into arm: of the sea, and the whole shape and form of the country cbanged. No wonder if, with so wide a room for speculation, different observers adopt somewhat different readings of this chapter of unwritten history. I have given you my reading of it, in which I see the antiquity of man carried back so far into the dim past, that even Egyptian chronology, extending as it does over thousands o years, appears but to cover a small link in the long chain of human existence-a chain of which the first link has still to be discovered. If you on your part will attempt to check and verify my reading, and study attentively what is still going on under your eyes, it will bring home to you the mighty effects which may arise from the small but ever-active agents, rains and rivers, tide and time; and whether in the end you agree with my reading or not, you will find that you have added a new int erest to your lives.

\section{PROFESSOR HAECKEL ON DARWIN, GOETHE, AND LAMARCK'}

WHEN five months ago the sad intelligence reached us by telegraph from England, that on April 19 Charles Darwin had concluded his life of rich activity, there thrilled with rare unanimity through the whole scientific world the feeling of an irreparable loss. Not only did the innumerable adberents and ${ }^{x}$ Lecture given at the Eisenach meeting of the German Naturalists and Physicians. 